\title{
Effects of soil amendment with PCB-contaminated sediment on the growth of two cucurbit species
}

\author{
Magdalena Urbaniak $^{1,2}$ (D) Sunmi Lee ${ }^{1} \cdot$ Mari Takazawa $^{1} \cdot$ Elżbieta Mierzejewska $^{2} \cdot$ Agnieszka Baran $^{3}$. \\ Kurunthachalam Kannan ${ }^{1,4}$
}

Received: 15 March 2019 / Accepted: 10 September 2019/Published online: 4 November2019

(C) The Author(s) 2019

\begin{abstract}
The aim of the study was to evaluate the influence of the application of increasing proportions $(0 \%, 10 \%, 25 \%, 50 \%, 75 \%$, and $100 \%$ ) of an admixture of PCB-contaminated Hudson River sediment collected from the Upper Hudson River, near Waterford, Saratoga county (New York, USA) on soil properties, phytotoxicity, and biometric and physiological responses of cucumber (Cucumis sativus L. cv 'Wisconsin SMR 58') and zucchini (Cucurbita pepo L. cv 'Black Beauty') grown as potential phyto- and rhizoremediators. The experiment was performed for 4 weeks in a growth chamber under controlled conditions. Amendment of Hudson River sediment to soil led to a gradual increase in PCB content of the substratum from $13.7 \mu \mathrm{g} / \mathrm{kg}$ (with $10 \%$ sediment) to $255 \mu \mathrm{g} / \mathrm{kg}$ (with $100 \%$ sediment). Sediment amendment showed no phytotoxic effects during the initial stages, even Lepidium sativum root growth was stimulated; however, this positive response diminished following a 4-week growth period, with the greatest inhibition observed in unplanted soil and zucchini-planted soil. The stimulatory effect remained high for cucumber treatments. The sediment admixture also increased cucurbit fresh biomass as compared to control samples, especially at lower doses of sediment admixture, even though PCB content of the soil amended with sediment increased. Cucurbits' leaf surface area, in turn, demonstrated an increase for zucchini, however only for $50 \%$ and $75 \%$ sediment admixture, while cucumber showed no changes when lower doses were applied and decrease for $75 \%$ and $100 \%$ sediment admixture. Chlorophyll $a+b$ decreased significantly in sediment-amended soils, with greater inhibition observed for cucumber than zucchini. Our results suggest that admixture of riverine sediment from relatively less-contaminated locations may be used as soil amendments under controlled conditions; however, further detailed investigation on the fate of pollutants is required, especially in terms of the bioaccumulation and biomagnification properties of PCBs, before contaminated sediment can be applied in an open environment.
\end{abstract}

Keywords PCBs $\cdot$ Hudson River $\cdot$ Sediment $\cdot$ Cucurbits $\cdot$ Phytoremediation $\cdot$ Rhizoremediation $\cdot$ Plant condition

Responsible editor: Philippe Garrigues

Magdalena Urbaniak

magdalena.urbaniak@biol.uni.lodz.pl

1 Wadsworth Center, New York State Department of Health, Empire State Plaza, P.O. Box 509, Albany, NY 12201-0509, USA

2 Department of Applied Ecology, Faculty of Biology and Environmental Protection, University of Lodz, Banacha 12/16, 90-237 Lodz, Poland

3 Faculty of Agriculture and Economics, Department of Agricultural and Environmental Chemistry, University of Agriculture in Krakow, Al. Mickiewicza 21, 31-120 Krakow, Poland

4 Department of Environmental Health Sciences, School of Public Health, State University of New York at Albany, New York, NY, USA

\section{Introduction}

The Hudson River flows for $507 \mathrm{~km}$ from its source in the Adirondack Mountains to Southern Manhattan, New York (NY), USA. The river is a cultural, social, commercial, recreational, and ecological resource for millions of people inhabiting the watershed (Pinkney et al. 2017). Between 1947 and 1977, large quantities of polychlorinated biphenyls (PCBs) were released into the upper section of the river from the capacitor-manufacturing operations at the General Electric (GE) plants at Hudson Falls and Fort Edward, NY. It is estimated that during that time, at least $590,000 \mathrm{~kg}$ of PCBs was released into the river (www.epa.gov/hudson/). PCBs bound to sediment particles pose a serious threat to this riverine 
ecosystem and human health. The removal of Fort Edward Dam in 1973 allowed for even greater discharge of PCBcontaminated sediments downstream, creating additional risk for biota and local communities. This resulted in a reduction in ecological and recreational value of the Hudson River, and prohibition of various activities, including recreational fishing (Hudson River Natural Resource Trustees 2015).

In 1984, the U.S. Environmental Protection Agency (US EPA) designated the nearly $322-\mathrm{km}$ section of the Hudson River from Hudson Falls to the southern tip of Manhattan as a Superfund Site (US EPA 2002). The site is divided into two parts: the Upper Hudson River, which covers the area from Hudson Falls to the Federal Dam at Troy (approximately $64 \mathrm{~km}$ ); and the tidal Lower Hudson River, covering the river section from the Federal Dam at Troy to the southern tip of Manhattan. In February 2002, the EPA finalized a Record of Decision for the Hudson River PCB Superfund Site that called for targeted environmental dredging of approximately 2.10 million $\mathrm{m}^{3}$ of PCB-contaminated sediment from a 64$\mathrm{km}$ section of the Upper Hudson River (www.epa.gov/ hudson/). Dredging started in 2009 and was finalized in 2015 , resulting in the removal of estimated $141,000 \mathrm{~kg}$ of PCBs (US EPA 2015). Un-dredged PCB residues, however, still constitute a threat for the river itself and the surrounding ecosystems, including the floodplain soil and groundwater, as well as the organisms that inhabit the ecosystem.

Remediation of the remaining PCB-contaminated sediments in situ poses many technological and logistical problems (Cho et al. 2001). The dredged sediment can be disposed in remote sites; however, PCB concentrations can be further reduced during or before disposal, with the use of plants (rhizo- and phytoremediation). Due to their hydrophobicity, and hence their strong adsorption to sediment and soil particles, PCBs only sparingly transfer to solution, and as a consequence, most plants only have limited potential to take up PCBs from sediment or soil (Briggs et al. 1982; Terzaghi et al. 2018b). One notable exception is the Cucurbitaceae family, including zucchini and cucumber, which readily takes up hydrophobic compounds, such as PCBs, from soil and translocates them to leaves and fruits (Greenwood et al. 2011; Matsuo et al. 2011; Low et al. 2011). It has been demonstrated that the members of Cucurbitaceae can phytoextract other organic compounds, including PCDDs/PCDFs (Engwall and Hjelm 2000; Hülster et al. 1994; Urbaniak et al. 2016), $p, p^{\prime}$-DDE (White 2002), DDT (Aslund et al. 2010), PAHs (Parrish et al. 2006), and chlordane (Mattina et al. 2000). Plants, including cucurbits, also play a key role in soil ecosystems by stabilizing soil structure, and stimulating soil microbial activity by serving as primary sources of organic matter and energy (Machado Vezzani et al. 2018). Moreover, due to existing interactions between plant roots, root exudates, soil, and microorganisms, microbeassisted phytoremediation (rhizoremediation) is thought to be the most effective method for the remediation of contaminated soil. Therefore, the use of cucurbits and associated rhizosphere bacteria appears to be a promising approach for the remediation of riverine sediments polluted with PCB mixtures and most likely other organic pollutants.

The overall aim of this study was to evaluate the suitability of sediment substrate amended to soils for the growth of common cucurbits, cucumber (Cucumis sativus L. cv 'Wisconsin SMR 58') and zucchini (Cucurbita pepo L. cv 'Black Beauty'). The influence of the river sediment on PCB content and phytotoxicity of soil-sediment mixtures were measured using Phytotoxkit and by growing cucumber and zucchini for 4 weeks at various doses of sediments amended to soil. In addition, to assess the effect of PCB-contaminated river sediments on biometric and physiological parameters of cucumber and zucchini, total aboveground biomass, leaf surface area, and chlorophyll $a+b$ content were determined.

\section{Materials and methods}

\section{Materials}

\section{Soil}

The vegetable potting soil was obtained from FoxFarm Soil \& Fertilizer Company (Arcata, California, USA). The soil composition was described as follows: aged forest products, sphagnum peat moss, Pacific Northwest Sea-going fish emulsion, crab meal, earthworm castings, sandy loam, perlite, fossilized bat guano, granite dust, Norwegian kelp meal, and oyster shell. The physico-chemical properties and PCB content of soil used in the experiment were determined (see section on soil and sediment physical and chemical properties), and the results are presented in Table $\mathbf{1 .}$

\section{Riverine sediments}

Riverine sediments were collected at a location upstream of Waterford village, at the Upper Hudson River Near Waterford (WTFN6) gauge station (Saratoga county, NY, USA) located above the Mohawk River tributary and above Champlain Canal Lock 1 (Lock One Rd., Waterford, NY). The sampling site (coordinates $42^{\circ} 49^{\prime} 36.9^{\prime \prime} \mathrm{N} 73^{\circ} 39^{\prime} 55.2^{\prime \prime} \mathrm{W}$ ) is located in the area of the Upper Hudson River PCB Superfund Site (www.epa. gov/hudson/). The hydrological parameters of the Hudson River at WTFN6 during the sampling period were as follows: flow $493 \mathrm{~m}^{3} / \mathrm{s}$, water stage $7 \mathrm{~m}$. Based on information from the National Weather Service-Advanced Hydrologic Prediction Service (www.water.weather.gov), the flood stage at the WTFN6 gauge station was $10.4 \mathrm{~m}$. Sediment samples were collected during stable hydrologic conditions. Sediment samples were collected using a grab sampler and transported to the laboratory where they were used as a vegetable potting 
Table 1 Physical and chemical properties of potting soil and Hudson River sediment collected above Waterford and used in the experiment

\begin{tabular}{|c|c|c|c|c|}
\hline Properties & $\begin{array}{l}\text { Vegetable } \\
\text { potting soil }\end{array}$ & $\begin{array}{l}\text { Hudson River } \\
\text { sediments }\end{array}$ & $\begin{array}{l}\text { TEC (threshold effect } \\
\text { concentration) }\end{array}$ & $\begin{array}{l}\text { PEC (probable effect } \\
\text { concentration) }\end{array}$ \\
\hline $\mathrm{pH}$ in $\mathrm{KCl}$ & 5.26 & 7.38 & - & - \\
\hline $\mathrm{pH}$ in $\mathrm{H}_{2} \mathrm{O}$ & 5.60 & 6.88 & - & - \\
\hline Salinity $(\mathrm{mS})$ & 0.88 & 3.21 & - & - \\
\hline TDS (g/L) & 0.45 & 1.61 & - & - \\
\hline \multicolumn{5}{|c|}{ Macroelements } \\
\hline TOC $(\%)$ & 36.4 & 1.69 & - & - \\
\hline $\mathrm{N}(\%)$ & 0.84 & 0.14 & - & - \\
\hline $\mathrm{S}(\%)$ & 0.27 & 0.06 & - & - \\
\hline $\mathrm{Ca}(\mathrm{g} / \mathrm{kg})$ & 11.0 & 2.24 & - & - \\
\hline $\mathrm{K}(\mathrm{g} / \mathrm{kg})$ & 1.28 & 1.14 & - & - \\
\hline $\mathrm{Mg}(\mathrm{g} / \mathrm{kg})$ & 2.51 & 1.78 & - & - \\
\hline$P(g / k g)$ & 0.87 & 4.01 & - & - \\
\hline $\mathrm{Na}(\mathrm{mg} / \mathrm{kg})$ & 351 & 140 & - & - \\
\hline $\mathrm{Fe}(\mathrm{g} / \mathrm{kg})$ & - & 3.06 & - & - \\
\hline \multicolumn{5}{|l|}{ Heavy metals } \\
\hline $\mathrm{Cd}(\mathrm{mg} / \mathrm{kg})$ & 0.66 & 0.28 & 0.99 & 4.98 \\
\hline $\mathrm{Cr}(\mathrm{mg} / \mathrm{kg})$ & 7.67 & 4.13 & 43.3 & 111 \\
\hline $\mathrm{Cu}(\mathrm{mg} / \mathrm{kg})$ & 9.86 & 6.48 & 31.6 & 149 \\
\hline $\mathrm{Mn}(\mathrm{mg} / \mathrm{kg})$ & 130 & 89.5 & - & - \\
\hline Ni (mg/kg) & 3.44 & 2.88 & 22.7 & 48.9 \\
\hline $\mathrm{Pb}(\mathrm{mg} / \mathrm{kg})$ & 4.25 & 1.95 & 35.8 & 128 \\
\hline $\mathrm{Zn}(\mathrm{mg} / \mathrm{kg})$ & 53.7 & 15.4 & 123 & 459 \\
\hline \multicolumn{5}{|c|}{ Organic compounds } \\
\hline $\begin{array}{l}\text { Total PCBs } \\
(\mu \mathrm{g} / \mathrm{kg})\end{array}$ & 0.41 & 255 & 59.8 & 676 \\
\hline
\end{tabular}

soil additive/amendment. The physico-chemical properties of the sediment were determined (see section on soil and sediment physical and chemical properties) and the results depicted in Table 1.

\section{Plants}

Seeds of cucumber (Cucumis sativus L. cv 'Wisconsin SMR 58'; purchased from Seeds'nSuch, Graniteville, South Carolina, USA) and zucchini (Cucurbita pepo L. cv 'Black Beauty'; purchased from Botanical Interests, Inc., Broomfield, Colorado, USA) were germinated in Petri dishes for 4 days to obtain seedlings of the same growth stage. Selected seedlings of the same size and at the same growth phase were planted in soil-sediment mixtures as described below.

\section{Experimental setup}

The vegetable potting soil was mixed with fresh Hudson River sediment, in the following proportions: $0 \%, 10 \%, 25 \%, 50 \%$, $75 \%$, and $100 \%$ river sediment. The proportion of soil and sediment was calculated based on their dry weight. To obtain homogenized samples, the sediment was mixed in a glass dish for $1 \mathrm{~h}$ using a stainless steel spatula; a similar procedure was adopted for vegetable potting soil. In order to prepare the soilsediment mixtures, river sediment and vegetable potting soil were thoroughly mixed for approximately $1 \mathrm{~h}$ using a stainless steel spatula. Each experiment was prepared in nine replicates in a polypropylene pot (capacity $400 \mathrm{~cm}^{3}$ ). Three replicates were incubated without plants; three were planted with cucumber and three with zucchini seedlings, with three seedlings per replicate (pot): nine seedlings in total per single treatment. The unplanted and planted (soil/sediment) samples were incubated for 4 weeks (28 days) in a growth chamber (Thermo Scientific Plant Growth Chamber 3768, Marietta, Ohio, USA) at $25 \pm 0.5{ }^{\circ} \mathrm{C}$ with a 16 -h light/8-h dark cycle, and $150 \pm$ $5 \mu \mathrm{mol} \mathrm{m} \mathrm{m}^{-2} \mathrm{~s}^{-1}$ photon flux density during the light period. All variants (planted and unplanted) were watered daily: the planted variants with $15-25 \mathrm{~mL}$ of water (depending on the plant's growth stage) and the unplanted variants with $15 \mathrm{~mL}$.

\section{Physical and chemical analysis of soil and sediment}

Samples of the soil and sediment mixture were air dried, and a Vario Max Cube analyzer was used to measure organic 
carbon, nitrogen, and sulfur content. In addition, trace elements were determined using an Optima 7300 DV inductively coupled plasma optical emission spectrophotometer (ICP$\mathrm{OES})$. The total concentrations of macroelements $\mathrm{Na}, \mathrm{Mg}$, $\mathrm{Ca}, \mathrm{K}, \mathrm{P}$, and $\mathrm{N}$ and heavy metals $\mathrm{Fe}, \mathrm{Mn}, \mathrm{Ni}, \mathrm{Cr}, \mathrm{Zn}, \mathrm{Pb}$, and $\mathrm{Cd}$ were determined after digestion in a mixture of $\mathrm{HNO}_{3}$ and $\mathrm{HClO}_{3}(3: 2 v / v)$.

\section{Soil-sediment mixture analysis}

\section{PCB analysis}

Soil-sediment mixture from each variant (in three replicates, each $400 \mathrm{~cm}^{3}$ ) was thoroughly mixed and homogenized using a stainless steel spatula in order to obtain one representative sample. A 100-g subsample was collected and freeze dried. After this step, the dried sample was again homogenized in a ceramic mortar, and subsample of $2 \mathrm{~g}$ was collected and subjected for analysis of PCB congeners (di-CBs-PCB-10/4, 6, 5/8, 15; tri-CBs-PCB-19, 17/18, 26, 31/28, 33/20, 22, 37; tetra-CBs-PCB-53, 51, 45, 52/73, 49/43, 44, 41, 64, 63, 74/ 61, 70/76, 60/56, 77; penta-CBs-PCB-93/95, 92/84, 90/101/ 89, 99, 119, 9/113, 110, 82, 123, 11/106, 114/122, 105/127; hexa-CBs-PCB-136, 151, 135/144, 149/139, 134, 146, 161, 153, 141, 137, 130, 138/164/163, 156, 157, 169; hepta-CBsPCB-187/182, 183, 174, 177, 171, 180, 193, 190; octa-CBsPCB-202, 201, 196/203, 95, 194, 205; nona-CBs-PCB-208 and 206; and deca-CB-PCB-209).

The sample was spiked with ${ }^{13} \mathrm{C}$-labeled internal standard (IS) mixture (PCB-LCS-H, $20 \mathrm{ng}$ each; Wellington Laboratories Inc., Guelph, Ontario, Canada) and extracted with hexane by an Accelerated Solvent Extractor (ASE 200; Dionex, Sunnyvale, California, USA) at $1500 \mathrm{psi}, 100{ }^{\circ} \mathrm{C}$. The samples were purified by passage through a multilayer silica column packed with neutral and acidic silica gel and elution with hexane. The extracts were further concentrated to $500 \mu \mathrm{L}$ under a gentle stream of nitrogen. The identification and quantification of PCB congeners were performed by Agilent Technologies 7890B GC coupled with 5977B MSD connected to a Zebron 5MS ( $15 \mathrm{~m}, 0.25 \mathrm{~mm}$ i.d., $0.10 \mu \mathrm{m}$ film thickness; Phenomenex, Torrance, California, USA) capillary column. The GC was operated in the split-less injection selected ion monitoring (SIM) mode. A 12-point calibration curve with concentrations that ranged from 0.05 to $200 \mathrm{ng} /$ $\mathrm{mL}$ was used to determine concentrations.

QA/QC protocols include IS method of quantification using certified calibration standards and labeled IS. Each analytical batch contained two procedural blanks, two matrix spikes (native standards spiked at $20 \mathrm{ng}$ ), and replicate analysis of samples. Recoveries ranged from $88.9 \%$ to $101 \%$ for diCBs, from $78.6 \%$ to $119 \%$ for tri-CBs, from $92.4 \%$ to $118 \%$ for tetra-CBs, from $83.3 \%$ to $92.1 \%$ for penta-CBs, from $85.7 \%$ to $102 \%$ for hexa-CBs, from $79.2 \%$ to $96.8 \%$ for
hepta-CBs, from $82.6 \%$ to $97.7 \%$ for octa-CBs, from $67.3 \%$ to $88.9 \%$ for nona-CBs, and $88.3 \%$ for deca-CB. Limit of quantitation was $0.05 \mu \mathrm{g} / \mathrm{kg}$.

\section{Phytotoxicity bioassay}

The phytotoxicity of soil and soil-sediment mixture was assessed using a Phytotoxkit, a commercial toxicity bioassay kit (Environmental Bio-Detection Product Inc., Mississauga, Ontario, Canada) (Phytotoxkit 2004). The test measured inhibition of root length of the test species, Lepidium sativum (L.), after $72 \mathrm{~h}$ of exposure to soil-sediment mixtures, in relation to root length of $L$. sativum exposed to uncontaminated, reference OECD soil delivered along with the test kit. The response of the test species was classified as toxic when the root length inhibition was $\geq 20 \%$ (Persoone et al. 2003).

\section{Plant analysis}

\section{Fresh biomass measurement}

The fresh biomass of cucumber and zucchini plants was measured after a 4-week (28 days) cultivation period. The plants were cut $1 \mathrm{~cm}$ above the soil surface and the fresh biomass of the above-ground parts was weighed.

\section{Leaf surface area measurement}

The leaves from each plant were collected after a 4-week (28 days) cultivation period and immediately scanned (within maximum $15 \mathrm{~min}$ after collection of each leaf to avoid losing of leaf turgor and shape that may influence on the measurement appropriateness) using a standardized template. The surface area of each leaf was measured using the ImageJ software package.

\section{Determination of chlorophyll content}

Chlorophyll content was measured in 4-week-old plants using the acetone method (Porra et al. 1989). Fresh leaves $(0.2 \mathrm{~g})$ of cucumber and zucchini were cut and homogenized in an icecold mortar. The crude homogenate obtained after filtration was assayed for chlorophyll content. The absorbance of a clear supernatant extract was measured at 663 and $645 \mathrm{~nm}$ using a Beckman DU 640 UV-Vis spectrophotometer.

\section{Statistical analysis}

Statistica 12.0 software and Microsoft Excel were used for all statistical analyses. The differences between the means were analyzed by two-way ANOVA and Tukey's test. The possible relationships between PCB concentration and physiological parameters of plants were evaluated using Pearson's 
correlation. Significance was determined based on a probability score of $p<0.05$.

\section{Results and discussion}

\section{Physico-chemical properties of soil and sediment medium}

Analyses of sediment properties are important for determining their potential as a soil amendment (Urbaniak et al. 2016; Tarnawski et al. 2017). For economic and ecological reasons, uncontaminated or less-contaminated dredged sediments are recommended for use in agriculture, especially for the cultivation of non-edible crops (Macía et al. 2014). Such agricultural utilization takes advantage of the beneficial properties of sediments, which are rich in clay, silt, organic matter, nutrients, and microbial activity (Karanam et al. 2008; Baran et al. 2010, 2012; Mattei et al. 2017). The Hudson River sediment collected at Waterford was neutral in $\mathrm{pH}\left(\mathrm{pH}_{\mathrm{KCl}}\right.$ 6.88), and rich in minerals, as measured by electrical conductivity $(3.21 \mathrm{mS} / \mathrm{cm})$ (Table 1). A neutral or alkaline sediment is a suitable amendment for acidic soils. Moreover, higher $\mathrm{pH}$ is associated with lower mobility of toxic heavy metals (Baran et al. 2012). Our sediments were relatively low in total organic carbon (TOC), nitrogen (N), and sulfur (S) (Table 1).

The ratio of $\mathrm{C} / \mathrm{N}$ has a direct influence on residue decomposition and nitrogen cycling, with greater decomposition occurring at lower ratios. In most soils, $\mathrm{C} / \mathrm{N}$ ratio lies in the range of $8: 1$ to $10: 1$, whereas a ratio $>30$ can result in $\mathrm{N}$ deficiencies. In our sediments, the average ratio of $\mathrm{C} / \mathrm{N}$ was 12 , which suggested that $\mathrm{N}$ is available for microbiological decomposition of organic matter. The sediments were rich in phosphorus $(\mathrm{P})$ and calcium $(\mathrm{Ca})$ but deficient in magnesium $(\mathrm{Mg})$, potas$\operatorname{sium}(\mathrm{K})$, and sodium $(\mathrm{Na})(\mathrm{P}>\mathrm{Ca}>\mathrm{Mg}>\mathrm{K}>\mathrm{Na})($ Table 1$)$.

The concentrations of heavy metals in sediment were assessed using sediment quality guideline values referred as threshold effect concentration (TEC) and probable effect concentration (PEC) (MacDonald et al. 2000). Comparison of soilsediment data with TEC indicated that collected sediments were non-toxic, as concentrations of metals were below the following thresholds: $123 \mathrm{mg} / \mathrm{kg}$ for $\mathrm{Zn}, 31.6 \mathrm{mg} / \mathrm{kg}$ for $\mathrm{Cu}$, $35.8 \mathrm{mg} / \mathrm{kg}$ for $\mathrm{Pb}, 0.99 \mathrm{mg} / \mathrm{kg}$ for $\mathrm{Cd}, 22.7 \mathrm{mg} / \mathrm{kg}$ for $\mathrm{Ni}$, and $43.3 \mathrm{mg} / \mathrm{kg}$ for $\mathrm{Cr}$. Similarly, sediment is predicted to be toxic when exceeding the following PEC values: $459 \mathrm{mg} / \mathrm{kg}$ for $\mathrm{Zn}$, $149 \mathrm{mg} / \mathrm{kg}$ for $\mathrm{Cu}, 128 \mathrm{mg} / \mathrm{kg}$ for $\mathrm{Pb}, 4.98 \mathrm{mg} / \mathrm{kg}$ for $\mathrm{Cd}$, $48.6 \mathrm{mg} / \mathrm{kg}$ for $\mathrm{Ni}$, and $111 \mathrm{mg} / \mathrm{kg}$ for $\mathrm{Cr}$. None of the metals analyzed in sediments exceeded the TEC or PEC values.

PCB content was $0.410 \mu \mathrm{g} / \mathrm{kg}$ in vegetable potting soil and $255 \mu \mathrm{g} / \mathrm{kg}$ in sediment. The sediment PCBs concentration can be regarded as "low to moderate contamination" as it exceeded the TEC (3.8-fold) but it was below the PEC (Table 1). The same is true when comparing values obtained with the newest studies from the Hudson River, e.g., Xu et al. (2019) report a PCB concentration of $1590 \mu \mathrm{g} / \mathrm{kg}$ in analyzed sediment, this being more than 6-fold higher than in our study, whereas Rodenburg and Ralston (2017) showed total PCB concentrations (sum of $132 \mathrm{PCB}$ ) ranging from $2.3 \mathrm{ng} / \mathrm{g}$ to $361 \mu \mathrm{g} / \mathrm{g}$ d.w. Our PCB content of $255 \mu \mathrm{g} / \mathrm{kg}$ is, however, much lower than historical data: Huan Feng et al. (1998) report PCB concentrations between 80 and $1290 \mu \mathrm{g} / \mathrm{kg}$, Achman et al. (1996) between 300 and $10 \mathrm{mg} / \mathrm{kg}$, Carchich and Tofflemiere (1982) as high as $50 \mathrm{mg} / \mathrm{kg}$, and Nadeau and Davis (1976) note concentrations as high as $6700 \mathrm{mg} / \mathrm{kg}$.

Relatively high $\mathrm{P}$ and Fe content and low toxic metal content (below TEC level) suggested that the sediment may be used as a soil amendment. However, the sediment was poor in TOC, $\mathrm{N}$, and $\mathrm{S}$, which requires amendments of macroelements for growing plants. Nonetheless, our results do not reflect the quality and agricultural value of the sediments, as dispersal of sediments on a vast land can lead to dissipation of PCBs and other contaminants into the environment. Our goal was to test to the phytotoxicity and suitability of sediment as an amendment for use in a confined facility. The open use of contaminated sediment may lead to the dispersal of PCBs in the environment, even if the PCB content was below the PEC. Consequently, further detailed study on the fate of PCBs after application to the environment is required. It is also important to note that sediments used for this experiment do not reflect the pollution status of the entire Hudson River. Collection of sediments from different sections of the river would provide more comprehensive information on the suitability of sediments as soil admixture.

\section{The effect of sediment and cucurbit growth on soil PCB content}

PCBs have low solubility in water and a strong tendency to adsorb on organic carbon; therefore, the most contaminated environmental matrices are soil and sediments. It is estimated that approximately $25 \%$ of the 1338 Superfund Sites in the USA (https://www.epa.gov/superfund/superfund-nationalpriorities-list-npl) are contaminated with PCBs. One of the most contaminated sites is the Hudson River Superfund Site (US EPA 2002), which is polluted with PCBs at concentrations ranging from nanograms per kilogram to hundreds of milligrams per kilogram in a number of locations (Xu et al. 2019; Rodenburg and Ralston 2017; Huan Feng et al. 1998; Carchich and Tofflemiere 1982; Achman et al. 1996; Nadeau and Davis 1976).

Several methods of PCB removal from sediments have been proposed. The most frequently used remediation technologies include dredging, dewatering, physical and chemical treatment (such as incineration), and landfilling. Since such approaches entail extensive costs, research is currently focused on the implementation of other more cost-effective 
and environmentally friendly remediation methods. One such method is phytoremediation, a method of pollutant removal based on the use of plants, especially those belonging to the cucurbit family, which are capable of taking up organic compounds from soil (Greenwood et al. 2011; Matsuo et al. 2011; Low et al. 2011; Engwall and Hjelm 2000; Hülster et al. 1994; White 2002; Aslund et al. 2010; Parrish et al. 2006; Mattina et al. 2000). Although certain plant species display good phytoextraction potential, the most effective method for the remediation of contaminated soil is thought to be rhizoremediation, a naturally occurring process within the plant root zone (rhizosphere), where the growth of microorganisms and their degradative activity are stimulated by root exudates (Mackova et al. 2006).

In our case, amendment of vegetable potting soil with Hudson River sediments led to a gradual increase in PCB content of the admixture/substratum: $0.410 \mu \mathrm{g} / \mathrm{kg}$ in control soil, $13.7 \mu \mathrm{g} / \mathrm{kg}$ when $10 \%$ of sediment was amended, $42.6 \mu \mathrm{g} / \mathrm{kg}$ for $25 \%$ sediment, $111 \mu \mathrm{g} / \mathrm{kg}$ for $50 \%$ sediment, $166 \mu \mathrm{g} / \mathrm{kg}$ for $75 \%$ sediment, and $255 \mu \mathrm{g} / \mathrm{kg}$ for $100 \%$ of sediment admixture (Fig. 1). Two-way analysis of variance showed that the content of PCBs in the growth medium was significant and did not depend on the variant of the experiment (unplanted and planted variant); however, our findings confirm that doses of bottom sediment have a strong effect (Table 2).

Over the 4-week cultivation period, zucchini planted samples demonstrated the most pronounced, however statistically unconfirmed, decrease in soil PCB content. In this case, an $8 \%$ decline in total PCB content was observed in the treatment with $25 \%$ sediment admixture; in contrast, a $16 \%$ decrease was observed for the treatments amended with $50 \%$ and $75 \%$ sediment (Fig. 1). For cucumber, amendments of $10 \%$, $25 \%$, and $75 \%$ sediment demonstrated a slight increase in total PCB content, whereas $50 \%$ and $100 \%$ sediment amendments showed a $2 \%$ and $6 \%$ decline in total PCB content, however again statistically not confirmed (Fig. 1).
Table 2 Two-way analysis of variance of the effects of (A) sediment dose $(0,10 \%, 25 \%, 50 \%, 75 \%, 100 \%)$ and (B) experimental variant (i.e., unplanted or planted variant) on the total PCB content of the growth medium

\begin{tabular}{llll}
\hline Effect & MS & $F$ & $p$ \\
\hline Dose of the bottom sediment (A) & $\mathbf{3 8 , 3 9 6 . 9}$ & $\mathbf{2 9 1 . 1 7 9}$ & $\mathbf{0 . 0 0 0 0 0 0}$ \\
Variant of the experiment (B) & 18.8 & 0.143 & 0.712354 \\
$\mathrm{~A} \times \mathrm{B}$ & 44.7 & 0.339 & 0.879811 \\
Error & 131.9 & & \\
\hline
\end{tabular}

The concentrations of the main PCB homologues are presented in Table 3, and the corresponding reductions in relation to the initial values are given in Table 4. Among the PCB homologues, the highest concentrations were noted for the lower chlorinated di-, tri-, and tetra-CB congeners, which amounted to $82-85 \%$ of the total PCB content. Such high predominance may indicate that light Aroclors (1242 and 1248) may be the main PCB source in the Hudson River sediments (Cho et al. 2001; Rodenburg and Ralston 2017). Four-week incubation led to changes in the concentrations of select PCBhomologue groups. The greatest reduction in concentrations was observed for zucchini (30 samples with a reduction ranging from $1 \%$ to $88 \%$ ), followed by cucumber ( 24 samples with a reduction ranging from $2 \%$ to $88 \%$ ) and the no-plant variant (23 samples with a reduction of $1 \%$ to $88 \%$ ) (Table 4). It is important to underline that the highest reductions of $88 \%$ were calculated based on LOQ value of $0.05 \mu \mathrm{g} / \mathrm{kg}$ and were observed only in the case of control samples. Among other variants, zucchini planted samples showed the highest reductions being as high as $83 \%$, followed by cucumber variants-with the highest observed reduction of $58 \%$, and unplanted samples - with the reductions up to $30 \%$. What is more, the highest reductions were noted for higher chlorinated PCBhomologue groups: hepta- and octa-PCBs (Table 4).
Fig. 1 Concentrations of PCBs in soil amended with different proportions of Hudson River sediment at the beginning of the experiment and after 4-week incubation: without plants, with cucumber, or with zucchini

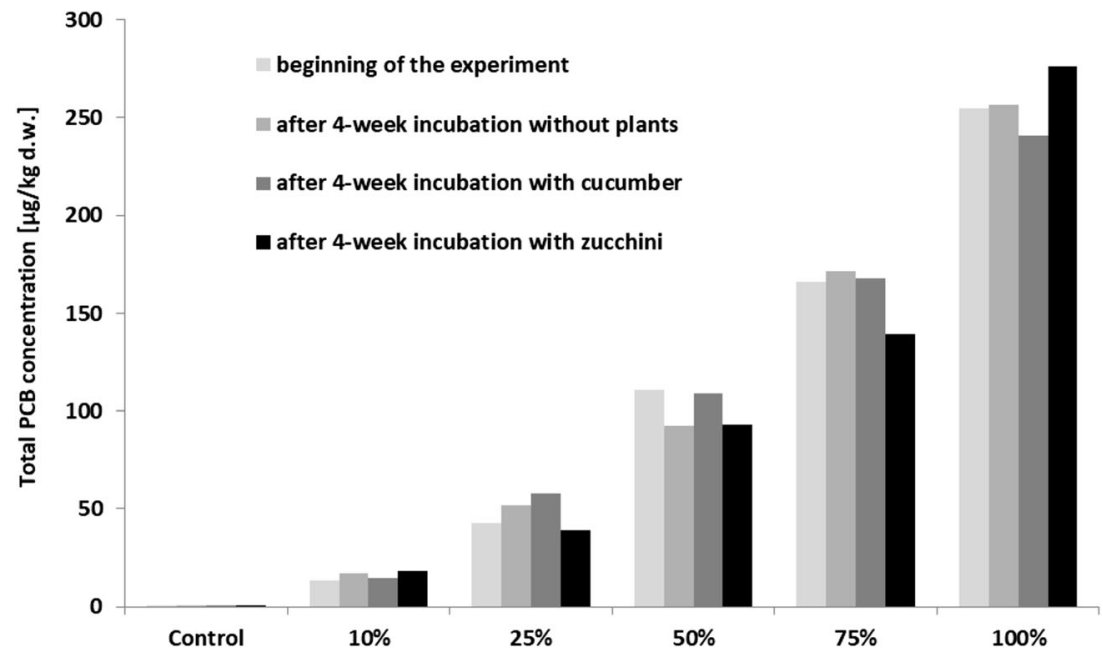


Table 3 Concentrations of PCB families in soil amended with different proportions of Hudson River sediment at the beginning of the experiment and after 4-week incubation: without plants, with cucumber, or with zucchini

\begin{tabular}{|c|c|c|c|c|c|c|c|c|c|c|}
\hline PCB-congener families & $\begin{array}{l}\mathrm{Di}- \\
\mathrm{CBs}\end{array}$ & $\begin{array}{l}\text { Tri- } \\
\text { CBs }\end{array}$ & $\begin{array}{l}\text { Tetra- } \\
\text { CBs }\end{array}$ & $\begin{array}{l}\text { Penta- } \\
\text { CB }\end{array}$ & $\begin{array}{l}\text { Hexa- } \\
\text { Cbs }\end{array}$ & $\begin{array}{l}\text { Hepta- } \\
\text { CBs }\end{array}$ & $\begin{array}{l}\text { Octa- } \\
\text { CBs }\end{array}$ & $\begin{array}{l}\text { Nona- } \\
\text { CBs }\end{array}$ & Deca-CB & Total \\
\hline Variants & \multicolumn{10}{|c|}{ Beginning of the experiment } \\
\hline Control & 0.41 & $<$ LOQ & $<$ LOQ & $<\mathrm{LOQ}$ & $<$ LOQ & $<$ LOQ & $<$ LOQ & $<$ LOQ & $<$ LOQ & 0.410 \\
\hline $10 \%$ & 2.60 & $<$ LOQ & 6.81 & 2.59 & 1.20 & 0.270 & 0.260 & $<$ LOQ & $<\mathrm{LOQ}$ & 13.7 \\
\hline $25 \%$ & 5.89 & 13.6 & 15.41 & 4.49 & 2.09 & 0.680 & 0.290 & 0.070 & 0.060 & 42.6 \\
\hline $50 \%$ & 17.3 & 30.0 & 44.75 & 10.8 & 5.35 & 1.56 & 0.660 & 0.250 & 0.090 & 111 \\
\hline $75 \%$ & 25.0 & 50.6 & 64.27 & 15.4 & 6.85 & 2.55 & 0.750 & 0.490 & 0.170 & 166 \\
\hline $100 \%$ & 43.5 & 87.2 & 80.6 & 26.8 & 10.6 & 3.86 & 1.45 & 0.490 & 0.210 & 255 \\
\hline \multicolumn{11}{|c|}{ After 4-week incubation without plants } \\
\hline Control & $<\mathrm{LOQ}$ & $<$ LOQ & $<$ LOQ & $<\mathrm{LOQ}$ & 0.690 & $<$ LOQ & 0.110 & $<$ LOQ & $<\mathrm{LOQ}$ & 0.790 \\
\hline $10 \%$ & 2.27 & 4.06 & 6.56 & 2.42 & 1.26 & 0.190 & 0.210 & $<$ LOQ & $<\mathrm{LOQ}$ & 17.0 \\
\hline $25 \%$ & 7.10 & 17.0 & 18.4 & 5.36 & 2.17 & 0.780 & 0.590 & $<\mathrm{LOQ}$ & $<\mathrm{LOQ}$ & 51.4 \\
\hline $50 \%$ & 13.7 & 23.4 & 35.0 & 12.6 & 5.32 & 1.40 & 0.530 & 0.320 & 0.110 & 92.4 \\
\hline $75 \%$ & 27.6 & 55.2 & 60.4 & 16.8 & 7.34 & 2.74 & 0.830 & 0.450 & 0.150 & 171 \\
\hline $100 \%$ & 41.5 & 88.3 & 87.5 & 23.7 & 9.56 & 3.82 & 1.06 & 0.490 & 0.190 & 256 \\
\hline \multicolumn{11}{|c|}{ After 4-week incubation with cucumber } \\
\hline Control & $<\mathrm{LOQ}$ & $<$ LOQ & 0.33 & $<\mathrm{LOQ}$ & 0.25 & $<$ LOQ & $<$ LOQ & $<$ LOQ & $<\mathrm{LOQ}$ & 0.570 \\
\hline $10 \%$ & 2.18 & 3.88 & 5.58 & 1.92 & 0.960 & 0.300 & 0.110 & $<$ LOQ & $<\mathrm{LOQ}$ & 14.9 \\
\hline $25 \%$ & 7.37 & 20.4 & 21.5 & 5.04 & 2.22 & 0.820 & 0.230 & 0.070 & 0.050 & 57.8 \\
\hline $50 \%$ & 16.5 & 35.1 & 38.8 & 10.3 & 4.65 & 1.80 & 0.580 & 0.670 & 0.230 & 108.7 \\
\hline $75 \%$ & 25.6 & 55.5 & 59.7 & 16.1 & 7.14 & 2.50 & 0.870 & 0.390 & 0.180 & 168 \\
\hline $100 \%$ & 41.1 & 79.7 & 83.0 & 22.2 & 9.19 & 3.57 & 1.00 & 0.460 & 0.180 & 240 \\
\hline \multicolumn{11}{|c|}{ After 4-week incubation with zucchini } \\
\hline Control & $<\mathrm{LOQ}$ & $<$ LOQ & 0.17 & $<\mathrm{LOQ}$ & 0.24 & $<$ LOQ & $<$ LOQ & $<$ LOQ & $<\mathrm{LOQ}$ & 0.410 \\
\hline $10 \%$ & 2.62 & 5.34 & 6.94 & 1.87 & 1.33 & 0.250 & $<$ LOQ & 0.080 & $<\mathrm{LOQ}$ & 18.4 \\
\hline $25 \%$ & 5.81 & 13.4 & 13.5 & 3.67 & 1.84 & 0.680 & $<\mathrm{LOQ}$ & 0.130 & $<\mathrm{LOQ}$ & 39.0 \\
\hline $50 \%$ & 15.2 & 31.7 & 30.7 & 8.73 & 3.74 & 1.81 & 0.380 & 0.360 & 0.100 & 92.8 \\
\hline $75 \%$ & 22.5 & 45.3 & 47.4 & 14.1 & 6.42 & 1.94 & 1.23 & 0.300 & 0.140 & 139 \\
\hline $100 \%$ & 47.2 & 86.1 & 102.2 & 25.6 & 9.30 & 4.45 & 0.540 & 0.460 & 0.190 & 276 \\
\hline
\end{tabular}

Plants have been shown to remove POPs from soils (Zhao et al. 2006; Susarla et al. 2002; Macek et al. 2000). However, our results indicate that only in the case of zucchini slight reduction in total PCB content in soil-sediment medium was observed. Urbaniak et al. (2016) reported that cultivation of zucchini (Cucurbita pepo cv. Atena Polka) in soil amended with sewage sludge reduced the concentrations of dioxins by $37 \%$ and decreased toxic equivalents (TEQ) by $68 \%$. Similarly, Wyrwicka et al. (2014) reported that cucumber reduced PCB content in sludge and sediment amended soil by $38.6 \%$ and $27.4 \%$, respectively, after 5 weeks of cultivation. It is important to note that phytoextraction capacities against organic compounds can vary between species and cultivars. Urbaniak et al. (2017a) found that zucchini was more effective in dioxin removal (37\% reduction) than cucumber (24\% reduction). Inui et al. (2008) found that among three tested $C$. pepo cultivars, 'Black Beauty' and 'Gold Rush' demonstrated 180-fold greater accumulation of organic compounds than 'Patty Green.'
Moreover, plants, particularly cucurbits, play an important role in PCB degradation due to a symbiotic relationship with plant growth-promoting bacteria. This symbiosis is related to a range of plant exudates released into the soil-root zone. Plant exudates not only support co-metabolic degradation processes by stimulating the proliferation and activity of PCB-degrading bacteria but also act as biostimulants that increase cell mass in the rhizosphere. Terzaghi et al. (2019), for example, demonstrated the positive role of long-term rhizostimulation in driving the modifications among soil microbiota, leading to its higher enzymatic activity and thus removal capabilities against PCBs. The authors showed that pumpkin (Cucurbita pepo ssp. pepo) is effective in reducing the concentration of PCBs; however, the most efficient removal is when it is co-cultivated with tall fescue and Rhizobium spp. and mycorrhizal fungi.

The plant exudates can also contain bio-surfactant molecules that play a crucial role in improving the bioavailability and degradation of PCBs (Vergani et al. 2017). The lack or 
Table 4 Reductions (\%) in the concentrations of PCB families after 4-week incubation (without plants, with cucumber, or with zucchini) in comparison to values determined at the beginning of experiment

\begin{tabular}{|c|c|c|c|c|c|c|c|c|c|c|}
\hline $\begin{array}{l}\text { PCB- } \\
\text { congener } \\
\text { families }\end{array}$ & $\begin{array}{l}\text { Di- } \\
\text { CBs }\end{array}$ & Tri-CBs & $\begin{array}{l}\text { Tetra- } \\
\text { CBs }\end{array}$ & $\begin{array}{l}\text { Penta- } \\
\text { CB }\end{array}$ & $\begin{array}{l}\text { Hexa- } \\
\text { Cbs }\end{array}$ & $\begin{array}{l}\text { Hepta- } \\
\text { CBs }\end{array}$ & $\begin{array}{l}\text { Octa- } \\
\text { CBs }\end{array}$ & $\begin{array}{l}\text { Nona- } \\
\text { CBs }\end{array}$ & $\begin{array}{l}\text { Deca- } \\
\text { CB }\end{array}$ & Total \\
\hline \multicolumn{11}{|c|}{ After 4-week incubation without plants } \\
\hline Control & $88^{*}$ & $0 *$ & $0^{*}$ & $0^{*}$ & $-1280^{*}$ & $0^{*}$ & $-120^{*}$ & $0^{*}$ & $0 *$ & -93 \\
\hline $10 \%$ & 13 & $-8020 *$ & 4 & 7 & -5 & 30 & 19 & $0^{*}$ & $0 *$ & -24 \\
\hline $25 \%$ & -21 & -25 & -20 & -19 & -4 & -15 & -103 & $29 *$ & $17^{*}$ & -21 \\
\hline $50 \%$ & 21 & 22 & 22 & -17 & 1 & 10 & 20 & -28 & -22 & 17 \\
\hline $75 \%$ & -10 & -9 & 6 & -9 & -7 & -7 & -11 & 8 & 12 & -3 \\
\hline $100 \%$ & 4 & -1 & -9 & 12 & 10 & 1 & 27 & 0 & 10 & -1 \\
\hline \multicolumn{11}{|c|}{ After 4-week incubation with cucumber } \\
\hline Control & $88^{*}$ & $0 *$ & $-560 *$ & $0^{*}$ & $-400^{*}$ & $0^{*}$ & $0^{*}$ & $0^{*}$ & $0 *$ & -39 \\
\hline $10 \%$ & 16 & $-7660 *$ & 18 & 26 & 20 & -11 & 58 & $0^{*}$ & $0 *$ & -9 \\
\hline $25 \%$ & -25 & -51 & -40 & -12 & -6 & -21 & 21 & 0 & 17 & -36 \\
\hline $50 \%$ & 4 & -17 & 13 & 4 & 13 & -15 & 12 & -168 & -156 & 2 \\
\hline $75 \%$ & -2 & -10 & 7 & -4 & -4 & 2 & -16 & 20 & -6 & -1 \\
\hline $100 \%$ & 5 & 9 & -3 & 17 & 14 & 8 & 31 & 6 & 14 & 6 \\
\hline \multicolumn{11}{|c|}{ After 4-week incubation with zucchini } \\
\hline Control & $88^{*}$ & $0 *$ & $-240 *$ & $0^{*}$ & $-380 *$ & $0^{*}$ & $0^{*}$ & $0^{*}$ & $0 *$ & 0 \\
\hline $10 \%$ & -1 & $-10,580$ & -2 & 28 & -11 & 7 & $81^{*}$ & $-60 *$ & $0 *$ & -34 \\
\hline $25 \%$ & 1 & 2 & 12 & 18 & 12 & 0 & $83^{*}$ & -86 & $17^{*}$ & 8 \\
\hline $50 \%$ & 12 & -6 & 31 & 19 & 30 & -16 & 42 & -44 & -11 & 16 \\
\hline $75 \%$ & 10 & 10 & 26 & 8 & 6 & 24 & -64 & 39 & 18 & 16 \\
\hline $100 \%$ & -9 & 1 & -27 & 5 & 13 & -15 & 63 & 6 & 10 & -8 \\
\hline
\end{tabular}

*Calculated based on LOQ value of $0.05 \mu \mathrm{g} / \mathrm{kg}$; negative values indicate increased concentration in relation to initial values at the beginning of experiment; positive values (grey) indicate reduction in relation to initial values at the beginning of experiment low removal of PCBs from sediments may be related to several factors including poor bioavailability of PCBs to plants. Moreover, the bacterial metabolism of PCB congeners may lead to the production of chlorobenzoates, dihydrodiols, dihydroxy-biphenyls, and other dead-end metabolites that exhibit toxic properties to microorganisms, affecting cell viability and thus inhibiting the entire PCB degradation process (Dai et al. 2002; Passatore et al. 2014). Consequently, the recalcitrance of PCBs to the applied remediation techniques and the low efficiency of the degradation process may be explained by the toxicity of certain metabolites generated during the PCBtransformation processes (Passatore et al. 2014).

It needs to be underlined that contaminated environmental matrices such as Hudson River sediments are mixtures not only of different congeners of PCBs, which differ with regard to their degradation pathways and intermediate degradation products, but they also include a range of other organic compounds (dioxins, polycyclic aromatic hydrocarbons) that may influence remediation efficiency. Consequently, the ongoing transformation processes may elicit several inhibition effects that in turn affect the efficiency of the remediation process (Dai et al. 2002; Passatore et al. 2014).

The relatively short incubation period used in the study may have an effect on our results. Tu et al. (2017) demonstrated that longer incubation times were associated with greater removal of PCB-77, with $62 \%, 73 \%$, and $91 \%$ removal observed after 45, 75, and 105 days of incubation. This increasing removal rate was also found to be associated with growing number of PCB-degrading bacterial genes, at 187\%, 279\%, and $483 \%$ of the initial soil after 45,75 , and 105 days of incubation, respectively. Liang et al. (2014) report $40 \%$ and $29.5 \%$ removal of the total PCB content in switchgrass planted and unplanted soil after 24 weeks (168 days). Kurzawova et al. (2012) demonstrated $40 \%$ and $25 \%$ PCB removal after 3-month incubation (90 days) with nightshade and tobacco, respectively. These findings suggest that both experiment duration and choice of suitable plant cultivars play key roles in the efficient removal of PCBs. With this in mind, extension of the incubation time could accelerate PCB degradation and enhance remediation efficiency.

\section{The effect of sediment and cucurbit growth on phytotoxicity}

One of the fast ecotoxicological tests available for assessing overall toxicity of a solid matrix (soil/sediment) is the Phytotoxkit bioassay. Phytotoxicity is defined as the presence of detrimental effects on various physiological processes of plants, such as seed germination and plant root elongation, caused by specific substances and general physico-chemical conditions present in the test matrix.

In this study, phytotoxicity of soil samples amended with the sediment collected from Hudson River was assessed using L. sativum as the test species. This plant species was selected based on our earlier studies (Urbaniak et al. 2016, 2017a, b), as well as those performed worldwide (Oleszczuk and Hollert 
2011; Oleszczuk et al. 2012; Ramirez et al. 2008a, b), that demonstrate it greatest sensitivity and suitability for assessing phytotoxicity of soil and sediments.

The soil-sediment mixtures were not found to have any toxic properties (inhibition of root length lower than 20\%) at the beginning of the experiment, nor after growth of cucumber and zucchini and natural attenuation (no plants). At the beginning of the experiment, all soil-sediment mixtures were found to stimulate $L$. sativum root growth, ranging from $-6 \%$ to $38 \%$. Nevertheless, this stimulation decreased over the 4week incubation period. The greatest inhibition was observed with sediment mixtures that did not have plants grown in them (inhibition between 6\% and 10\%) and for zucchini planted samples (from 2\% to 19\%) (Table 5). Soil-sediment mixtures grown with cucumber demonstrated high stimulation of L. sativum root growth, being $-27 \%,-28 \%,-20 \%$, and $11 \%$ for $0 \%, 10 \%, 25 \%$, and $100 \%$ of sediment admixture (Table 5). An admixture of 50\% and 75\% sediment led to slight inhibition of $L$. sativum root length, the degree of reduction being $11 \%$ and $1 \%$, respectively; similarly, minor inhibition was noted for the no-plant variant (inhibition of $6 \%$ and $10 \%$ ). Nevertheless, as none of the inhibition values obtained for cucumber variants exceeded the $20 \%$ threshold, the soilsediment mixtures grown with this plant species cannot be regarded as toxic (Table 5). Soil-sediment admixtures taken from both plant species displayed significant differences in phytotoxicity between the beginning and the end of the 4week cultivation period. Treatments with cucumber presented statistically significant differences in phytotoxicity from those planted with zucchini (Table 5).

The stimulation of $L$. sativum root growth observed in sediment-amended soil could possibly be due to the composition of the amendment and good water retention capacity of soil-sediment treatments. The Hudson River sediment was rich in $\mathrm{P}$ and $\mathrm{Fe}$ (Table 1). These properties alleviate the toxic effects of PCBs and other pollutants, which manifest themselves in increased $L$. sativum root growth. The decrease in the stimulation observed in unplanted soil can be related to leaching of macronutrients from soil-sediment mixture during the incubation period: the pots were systematically watered to keep the experimental conditions same with planted treatments during the entire incubation time. Only $100 \%$ sediment maintained the same level of stimulatory effect; however, this medium was characterized by a dense sediment structure, preventing the leaching of macroelements. Moreover, the presence of high TOC in the soil may influence PCB behavior in the prepared soil-sediment mixtures; according to Terzaghi et al. (2018a), organic carbon, especially in a dissolved form, not only increased PCB bulk water concentration acting as a "spoon feeder" for bacteria but also enhanced PCB degradation through mediating the infiltration. Consequently, different proportions of soil, rich in TOC, and sediments, characterized by 22 -fold lower TOC content, could have an impact on the soil parameters such as PCB content and phytotoxicity.

Different patterns were observed for treatments with plants, with significantly higher stimulation observed for cucumber than zucchini (Table 5). Such variation can be related to species-specific properties, as well as differences in the activity of soil-sediment microbiota under the influence of host cucurbits as plant nutrient preference influences the activity of rhizosphere microbiome. Cai et al. (2017) found that cultivation with cucumber resulted in a different soil microbiota profile than tomato cultivation. Poli et al. (2016) also presented the role of plant genotype on rhizosphere microbiota. Consequently, species-specific nutrient preferences and species-dependent root exudates may influence the overall phytotoxicity of samples through their influence on soil properties and soil-sediment microbial activity.
Table 5 Phytotoxicity of samples measured using L. sativum as a test plant; calculated in reference to OECD soil

\begin{tabular}{lllll}
\hline Sediment dose & $\begin{array}{l}\text { Beginning of the } \\
\text { experiment }\end{array}$ & After 4-week cultivation period & \\
\cline { 3 - 5 } & & No plant & Cucumber & Zucchini \\
\hline Control & $-31^{\mathrm{a}}$ & $-6^{\mathrm{a}}$ & $-27^{\mathrm{a}, \mathrm{c}, \mathrm{d}}$ & $14^{\mathrm{b}, \mathrm{c}, \mathrm{d}}$ \\
$10 \%$ & $-18^{\mathrm{a}}$ & $8^{\mathrm{b}}$ & $-28^{\mathrm{a}, \mathrm{c}, \mathrm{d}}$ & $7^{\mathrm{b}, \mathrm{c}, \mathrm{d}}$ \\
$25 \%$ & $-6^{\mathrm{a}}$ & $8^{\mathrm{b}}$ & $-20^{\mathrm{a}, \mathrm{c}, \mathrm{d}}$ & $-2^{\mathrm{a}, \mathrm{c}, \mathrm{d}}$ \\
$50 \%$ & $-38^{\mathrm{a}}$ & $6^{\mathrm{b}}$ & $11^{\mathrm{b}, \mathrm{c}, \mathrm{d}}$ & $2^{\mathrm{b}, \mathrm{c}, \mathrm{d}}$ \\
$75 \%$ & $-31^{\mathrm{a}}$ & $10^{\mathrm{b}}$ & $1^{\mathrm{b}, \mathrm{c}, \mathrm{d}}$ & $10^{\mathrm{b}, \mathrm{c}, \mathrm{d}}$ \\
$100 \%$ & $-20^{\mathrm{a}}$ & $-22^{\mathrm{a}}$ & $-11^{\mathrm{a}, \mathrm{c}, \mathrm{d}}$ & $19^{\mathrm{b}, \mathrm{c}, \mathrm{d}}$ \\
\hline
\end{tabular}

No asterisk — statistically non-significant results

${ }^{\text {a }}$ Negative values indicate stimulation of $L$. sativum root growth in comparison to uncontaminated reference soil (OECD soil derived with the Phytotoxkit test)

${ }^{\mathrm{b}}$ Positive values indicate inhibition of the $L$. sativum root growth in comparison to uncontaminated reference soil (OECD soil derived with the Phytotoxkit test)

${ }^{\mathrm{c}}$ Statistically significant in comparison to the beginning of the experiment

${ }^{\mathrm{d}}$ Statistically significant in comparison to no plant variant after 4 -week incubation 
The effect of sediment application on cucurbit growth and biomass

Although several studies concerning the environmental impact of PCBs as well as PCB-contaminated sediments, including Hudson River sediments, exists in the literature, these studies mainly address contamination levels in situ and the effects of PCBs on animals such as fish (Field et al. 2016; Pinkney et al. 2017; Maceina and Sammons 2015), birds (Madden and Skinner 2016; Baker et al. 1976; Foley 1992; Kim et al. 1984, 1985; O'Keefe et al. 2006), or invertebrates (Cho et al. 2004). In contrast, our study examines the effect of sediments on plants. Whereas the abundance of organic matter and nutrients, especially P, makes sediments a good source of nutrients, the presence of organic pollutants may place stress on plants. Our findings demonstrate the varying responses of cucurbits to the application of Hudson River sediments.

Our results indicate that cultivation of cucurbits on soil amended with sediments from the Hudson River near Waterford, especially at lower doses, significantly increased fresh biomass compared to controls (i.e., 0\% sediment). However, the response of plants to PCB-contaminated sediments was significantly dependent on both species and dose. In the case of cucumber, only the $10 \%$ and $25 \%$ sediment admixtures led to significant higher aboveground biomass production (114\% and $126 \%$ of the control, respectively). Higher doses of $50 \%, 75 \%$, and $100 \%$ sediment admixtures significantly reduced aboveground biomass production in comparison to control $(89 \%, 73 \%$, and $23 \%$, of the control, respectively) (Fig. 2). In the case of zucchini, the sediments appeared to have a positive influence on aboveground plant biomass, which was found to significantly increase with the proportion of sediment: this increase was found to be $132 \%, 138 \%, 160 \%$, and $140 \%$ of control values for $10 \%, 25 \%, 50 \%$, and $75 \%$ sediment admixtures, respectively; only $100 \%$ sediment admixture caused significant lower zucchini aboveground biomass ( $82 \%$ of the control) (Fig. 2). The results also demonstrated a significant increase in the zucchini leaf surface area in variants amended with $50 \%$ and $75 \%$ sediment admixtures (Fig. 3). For cucumber, in turn, $10 \%, 25 \%$, and $50 \%$ sediment admixtures did not reveal significant changes in the leaf surface area, while application of higher doses led to significant decrease in the leaf surface area in comparison to control plants (Fig. 3). However, correlation analyses confirmed a significant positive correlation between leaf surface area and biomass of both plants. An increase in plant biomass following sediment amendment was also reported by Karak et al. (2013) for mustard. However, no correlation was found between an increased biomass and greater leaf surface area with the production of photosynthetic pigments by zucchini; this stands in contrast with cucumber, where such correlations have been recorded (Fig. 4, Table 6).

The application of sediments led to significantly lower production of chlorophyll $a+b$ by both plants. However,

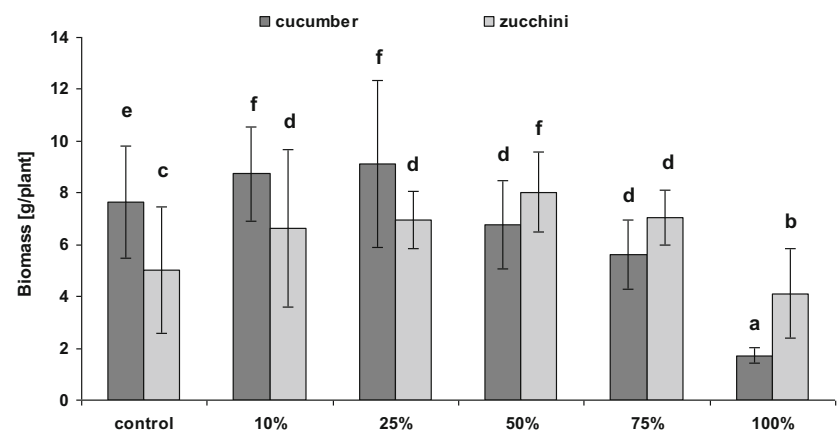

Fig. 2 Mean $( \pm \mathrm{SD})$ fresh aboveground biomass of cucumber and zucchini (after 4 weeks) cultivated in soil amended with different proportions of Hudson River sediments. Error bars indicate standard deviation $(n=9)$. Letters denote a significant difference with $p>0.05$ (the Tukey post hoc test)

cucumber was more sensitive to the sediment than zucchini and demonstrated lower production of photosynthetic pigment with regard to $10 \%, 25 \%, 50 \%, 75 \%$, and $100 \%$ sediment amendment: $87 \%, 76 \%, 63 \%, 48 \%$, and $44 \%$ of control values for cucumber, and $99 \%, 82 \%, 94 \%, 76 \%$, and $70 \%$ for zucchini (Fig. 4).

Correlation analyses also found cucumber to display greater sensitivity, wherein a higher number of statistically significant dependences between PCB content and biometric and physiological parameters were obtained for cucumber than zucchini (Table 6). While the correlation between total PCB concentration and plant parameters was generally negative for both tested species, for zucchini, only chlorophyll content was significantly negatively correlated with total PCB concentration in the growing medium. Regardless of the species, the highest values of the correlation coefficient were observed between chlorophyll $a+$ $b$ and PCB content (Table 6). This suggests that chlorophyll $a+b$ measurement is a suitable indicator of plant stress on PCB concentration in the growing medium. Wyrwicka et al. (2019)

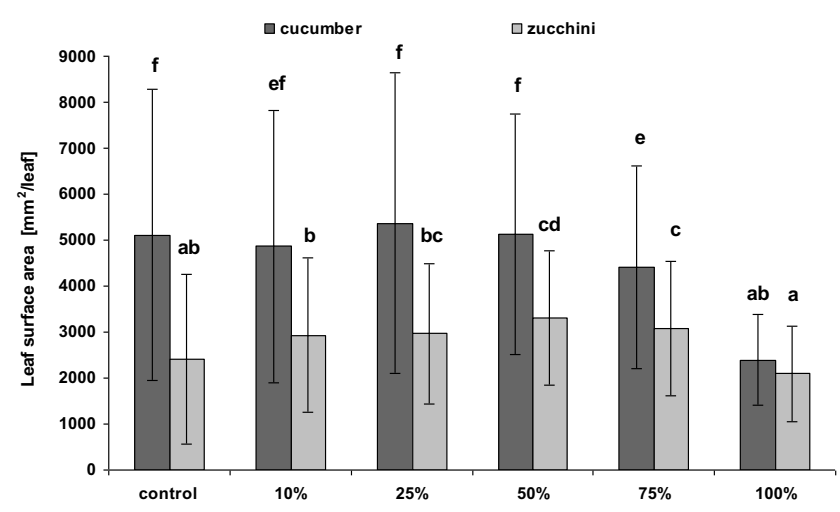

Fig. 3 Mean ( \pm SD) leaf surface area of cucumber of zucchini cultivated in soil (after 4 weeks) amended with different proportions of Hudson River sediments. Error bars indicate standard deviation $(n$ values for cucumber-control $=32 ; 10 \%=42 ; 25 \%=41 ; 50 \%=38 ; 75 \%=32$; $100 \%=16 ; n$ values for zucchini-control $=31 ; 10 \%=32 ; 25 \%=41$; $50 \%=44 ; 75 \%=41 ; 100 \%=34)$. Letters denote a significant difference with $p>0.05$ (the Tukey post hoc test) 
Fig. 4 Mean $( \pm \mathrm{SD})$ chlorophyll $a+b$ content in the leaves of cucumber and zucchini (after 4 weeks) cultivated in soil amended with different proportions of Hudson River sediments. Error bars indicate standard deviation $(n=9)$. Letters denote a significant difference with $p>0.05$ (the Tukey post hoc test)

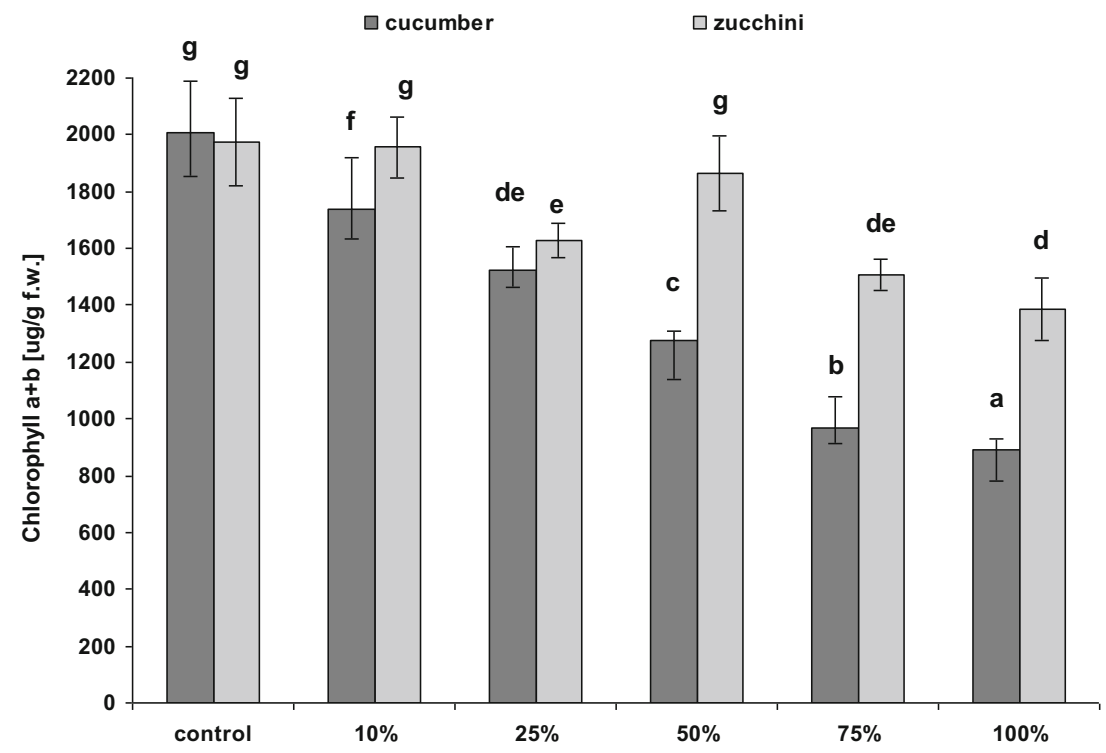

report that total chlorophyll content, together with chlorophyll $a / b$ ratio, were good indicators of the initiation of plant senescence and changes in the biochemical processes in cucumber plants following the application of PCB-contaminated sewage sludge and urban sediment. Reduced chlorophyll content is one of the first symptoms of plant senescence, which is connected with the breakdown of thylakoid membranes and the degradation of thylakoid-bound proteins; hence, chlorophyll content have previously been used as indicators of plant aging (Prochazkova et al. 2001; Nath et al. 2013; Gomes et al. 2016).

\section{Conclusions}

Our findings revealed a complex nature of Hudson River sediment for its potential use as a growth medium after amendments with soil. Although sediment represents a valuable source of $\mathrm{P}, \mathrm{Fe}$, and $\mathrm{Ca}$, it is contaminated with PCBs that exceed TEC. Thus, soil-sediment mixtures can result in diverse responses with regard to phytotoxicity and the health of plants grown therein. PCB content of soil increased following amendment with sediment. However, sediment admixture stimulated L. sativum root growth at the beginning of the experiment. After 4-week cultivation period, zucchini grown soil-sediment substratum demonstrated slight inhibition of L. sativum growth, whereas cucumber grown substratum stimulated root growth of L. sativum compared to controls. The biomass of cucumber was lower than that of control at almost all applied doses of sediment. Zucchini showed increased biomass in all soil-sediment mixtures except for $100 \%$ sediment. Dose- and speciesdependent responses were observed for plant leaf surface area being significantly higher for zucchini amended with $50 \%$ and $75 \%$ of sediment. Cucumber, in turn, showed a reverse trend with significantly lower leaf surface area for $50 \%$ and $75 \%$ sediment admixture. Chlorophyll content of cucumber and zucchini decreased with increasing sediment doses. Zucchini was found to be more resistant than cucumber to sediment amendment of soil. Moreover, zucchini planted samples showed higher, however statistically unconfirmed, reduction of the total PCBs than cucumber and unplanted samples following the 4-week incubation period. The degree of remediation could well be affected by extending the duration of the experiment, as well as application of other cucurbit cultivars. Further studies are intended to evaluate the accumulation of PCBs in tissues of cultivated plants and to assess of the fate of the pollutants under environmental conditions instead of controlled laboratory conditions.
Table 6 Relationships between content of PCB in the soilsediment mixtures and the biometric and physiological parameters of the cucumber and zucchini grown therein

\begin{tabular}{|c|c|c|c|c|c|c|}
\hline \multirow[t]{2}{*}{ Parameter } & \multicolumn{3}{|l|}{ Cucumber } & \multicolumn{3}{|l|}{ Zucchini } \\
\hline & PCB & Biomass & Leaf surface & PCB & Biomass & Leaf surface \\
\hline Biomass & $-0.905^{*}$ & & & -0.414 & & \\
\hline Leaf surface & $-0.826^{*}$ & $0.940 *$ & & -0.432 & $0.997 *$ & \\
\hline Chlorophyll & $-0.964 *$ & $0.768 *$ & $0.677^{*}$ & $-0.845^{*}$ & 0.339 & 0.323 \\
\hline
\end{tabular}

*Significant at $p \leq 0.05$ 
Acknowledgments The study was supported by the Kosciuszko Foundation Exchange Program to Magdalena Urbaniak for travel to the USA. The authors would like to thank Mr. Karl Brosch at Wadsworth Center, NYSDOH, for his assistance in conducting the study, and Dr. Hongkai Zhu and Mr. Jin Park for their help during sediment sampling.

Open Access This article is distributed under the terms of the Creative Commons Attribution 4.0 International License (http:// creativecommons.org/licenses/by/4.0/), which permits unrestricted use, distribution, and reproduction in any medium, provided you give appropriate credit to the original author(s) and the source, provide a link to the Creative Commons license, and indicate if changes were made.

\section{References}

Achman DR, Brownawell BJ, Zhang L (1996) Exchange of polychlorinated biphenyls between sediment and water in the Hudson River estuary. Estuaries 19(4):950-965

Aslund MLW, Lunney AL, Rutter A, Zeeb BA (2010) Effects of amendments on the uptake and distribution of DDT in Cucurbita pepo ssp pepo plants. Environ Pollut 158:508-513

Baker F, Tumasonis C, Stone W, Bush B (1976) Levels of PCB and trace metals in waterfowl in New York State. NY Fish Game J 23:82-91

Baran A, Jasiewicz C, Tarnawski M (2010) Effect of bottom deposit on trace element content in light soil. Ecol Chem Eng A 17(12):1553-1561

Baran A, Jasiewicz C, Tarnawski M (2012) Effect of bottom sediment supplement to light soil on the content and uptake of macroelements by maize. Ecol Chem Eng A 19(8):863-872

Briggs GG, Bromilow RH, Evans AA (1982) Relationships between lipophilicity and root uptake and translocation of non-ionised chemicals by barley. Pestic Sci 13:495-504

Cai F, Pang G, Miao Y, Li R, Li R, Shen Q, Chen W (2017) The nutrient preference of plants infuences their rhizosphere microbiome. Appl Soil Ecol 110:146-150

Carchich IG, Tofflemiere TJ (1982) Distribution and concentration of PCB in the Hudson River and associated management problems. Environ Int 7:73-85

Cho T-C, Kwon O-S, Sokol RC, Bethoney CM, Rhee G-Y (2001) Microbial PCB dechlorination in dredged sediments and the effect of moisture. Chemosphere 43:1119-1126

Cho Y-C, Frohnhoefera RC, Rhee G-Y (2004) Bioconcentration and redeposition of polychlorinated biphenyls by zebra mussels (Dreissena polymorpha) in the Hudson River. Water Res 38(3): 769-777

Dai S, Vaillancourt FH, Maaroufi H, Drouin NM, Neau DB, Snieckus V, Bolin JT, Eltis LDE (2002) Identification and analysis of a bottleneck in PCB biodegradation. Nat Struct Biol 9:934-939

Engwall M, Hjelm K (2000) Uptake of dioxin-like compounds from sewage sludge into various plant species - assessment of levels using a sensitive bioassay. Chemosphere 40:1189-1195

Field LJ, Kern JW, Rosman LB (2016) Re-visiting projections of PCBs in lower Hudson River fish using model emulation. Sci Total Environ 557-558:489-501

Foley RE (1992) Organochlorine residues in New York waterfowl harvested by hunters in 1983-1984. Environ Monit Assess 21:37-48

Gomes MP, Le Manach SH, Maccario S, Labrecque M, Lucotte M, Juneau $P$ (2016) Differential effects of glyphosate and aminomethylphosphonic acid (AMPA) on photosynthesis and chlorophyll metabolism in willow plants. Pestic Biochem Physiol 130:65-70

Greenwood SJ, Rutter A, Zeeb BA (2011) The absorption and translocation of polychlorinated biphenyl congeners by Cucurbita pepo ssp pepo. Environ Sci Technol 45:6511-6516

Huan Feng J, Cochran K, Lwiza H, Brownawell BJ, Hirschberg DJ (1998) Distribution of heavy metal and PCB contaminants in the sediments of an urban estuary: the Hudson River. Mar Environ Res 45(1):69-88

Hudson River Natural Resource Trustees (HRNRT) (2015) Injuries to Hudson River fishery resources: fishery closures and consumption restriction. Updated final report, State of New York, U.S. Department of Commerce, U.S. Department of the Interior. (Available from NOAA, Silver Spring, MD)

Hülster A, Müller JF, Marschner H (1994) Soil-plant transfer of polychlorinated dibenzo-p-dioxins and dibenzofurans to vegetables of the cucumber family (Cucurbitaceae). Environ Sci Technol 28: $1110-1115$

Inui H, Wakai T, Gion K, Kim YS, Eun H (2008) Differential uptake for dioxin-like compounds by zucchini subspecies. Chemosphere 73 : 1602-1607

Karak T, Bhattacharyya P, Paul RK, Das DK (2013) Metal accumulation, biochemical response and yield of Indian mustard grown in soil amended with rural roadside pond sediment. Ecotoxicol Environ Saf 92:161-173

Karanam PV, Wani SP, Sahrawat KL, Jangawad LS (2008) Economic evaluation of sediment as a source of plant nutrients. Curr Sci 95(25):1042-1050

Kim KS, Pastel MJ, Kim JS, Stone WB (1984) Levels of polychlorinated biphenyls, DDE, and mirex in waterfowl collected in New York State, 1979-1980. Arch Environ Contam Toxicol 13:373-381

Kim HT, Kim KS, Kim JS, Stone WB (1985) Levels of polychlorinated biphenyls (PCBs), DDE, and mirex in waterfowl collected in New York State, 1981-1982. Arch Environ Contam Toxicol 14:13-18

Liang Y, Meggo R, Hu D, Schnoor JL, Mattes TE (2014) Enhanced polychlorinated biphenyl removal in a switchgrass rhizosphere by bioaugmentation with Burkholderia xenovorans LB400. Ecol Eng $72: 215-222$

Low JE, Aslund MLW, Rutter A, Zeeb BA (2011) The effects of pruning and nodal adventitious roots on polychlorinated biphenyl uptake by Cucurbita pepo grown in field conditions. Environ Pollut 159:769-775

MacDonald DD, Ingersoll CG, Berger TA (2000) Development and evaluation of consensus-based sediment quality guidelines for freshwater ecosystems. Arch Environ Contam Toxicol 39:20-31

Maceina MJ, Sammons SM (2015) Polychlorinated biphenyl exposure and fish recruitment from 1988 to 2002 in the upper Hudson River, New York, USA. Fish Res 170:228-236

Macek T, Mackova M, Kas J (2000) Exploitation of plants for the removal of organics in environmental remediation. Biotechnol Adv 18:23-34

Machado Vezzani F, Anderson C, Meenke E, Gillespie R, Peterson M, Michael Harold Beare MH (2018) The importance of plants to development and maintenance of soil structure, microbial communities and ecosystem functions. Soil Tillage Res 175:139-149

Macía SP, Fernández-Costas C, Rodríguez E, Sieiro P, Pazos M, Sanromán MA (2014) Technosols as a novel vaporization strategy for an ecological management of dredged marine sediment. Ecol Eng 67:182-189

Mackova M, Dowling D, Macek T (eds) (2006) Phytoremediation and rhizoremediation. Springer 978-1-4020-4999-6

Madden SS, Skinner LC (2016) Polychlorinated biphenyls (PCBs) in adult and juvenile mallards (Anas platyrhynchos) from the Hudson River, New York, USA. Environ Pollut 216:487-499

Matsuo S, Yamazaki K, Gion K, Eun H, Inui H (2011) Structure-selective accumulation of polychlorinated biphenyls in Cucurbita pepo. J Pestic Sci 36(3):363-369

Mattei P, D'Acqui LP, Nicese FP, Lazzerini G, Masciandaro G, Macci C, Doni S, Sarteschi F, Giagnoni L, Renella G (2017) Use of phytoremediated sediments dredged in maritime port as plant nursery growing media. J Environ Manag 186:225-232

Mattina MI, Iannucci-Berger W, Dykas L (2000) Chlordane uptake and its translocation in food crops. J Agric Food Chem 48:1909-1915 
Nadeau RJ, Davis RA (1976) Polychlorinated biphenyls in the Hudson River (Hudson Falls - Fort Edward, New York State). Bull Environ Contam Toxicol 16:436-444. https://doi.org/10.1007/BF01686159

Nath K, Phee B-K, Suyeong J, Lee SY, Tateno Y, Allakhverdiev SI, Lee C-H, Nam HG (2013) Age-dependent changes in the functions and compositions of photosynthetic complexes in the thylakoid membranes of Arabidopsis thaliana. Photosynth Res 117:547-556

O'Keefe PW, Clayton WC, Connor S, Bush B, Hong CS (2006) Organic pollutants in wild ducks from New York State: I. Interspecies differences in concentrations and congener profiles of PCBs and PCDD/PCDFs. Sci Total Environ 361:111-123

Oleszczuk P, Hollert H (2011) Comparison of sewage sludge toxicity to plants and invertebrates in three different soils. Chemosphere 83(4): 502-509

Oleszczuk P, Malara A, Jośko I, Lesiuk A (2012) The phytotoxicity changes of sewage sludge-amended soils. Water Air Soil Pollut 223(8):4937-4948

Parrish ZD, White JC, Isleyen M, Gent MPN, Iannucci-Berger W, Eitzer BD, Kelsey JW, Mattina MI (2006) Accumulation of weathered polycyclic aromatic hydrocarbons (PAHs) by plant and earthworm species. Chemosphere 64:609-618

Passatore L, Rossetti SA, Juwarkar AA, Massacci A (2014) Phytoremediation and bioremediation of polychlorinated biphenyls (PCBs): state of knowledge and research perspectives. J Hazard Mater 278:189-202

Persoone G, Marsalek B, Blinova I, Torokne A, Zarina D, Manusadzianas L, Nalecz-Jawecki G, Tofan L, Stepanova N, Tothova L, Kolar B (2003) A practical and user-friendly toxicity classification system with microbiotest for natural waters and wastewaters. Environ Toxicol 18(6):395-402

Phytotoxkit (2004) Seed germination and early growth microbiotest with higher plants. MicroBioTest Inc., Nazareth, p 24

Pinkney AE, Myers MS, Rutter MA (2017) Histopathology of brown bullhead (Ameiurus nebulosus), smallmouth bass (Micropterus dolomieu), and yellow perch (Perca flavescens) in relation to polychlorinated biphenyl (PCB) contamination in the Hudson River. Sci Total Environ 575:1325-1338

Poli A, Lazzari A, Prigione V, Voyron S, Spadaro D, Varese GC (2016) Influence of plant genotype on the cultivable fungi associated to tomato rhizosphere and roots in different soils. Fungal Biol 120(67):862-872

Porra RJ, Thompson WA, Kriedmann PE (1989) Determinate of accurate extinction coefficients and simultaneous equations for assaying chlorophylls $\mathrm{a}$ and $\mathrm{b}$ extracted with four different solvents: verification of the concentration of chlorophyll standards by atomic absorption spectroscopy. Biochim Biophys Acta 975:384-339

Prochazkova D, Sairam RK, Srivastava GC, Singh DV (2001) Oxidative stress and antioxidant activity as the basis of senescence in maize leaves. Plant Sci 161:765-771

Ramirez WA, Domene X, Andreas P, Alcanitz JM (2008a) Phytotoxic effects of sewage sludge extracts on the germination of three plant species. Ecotoxicol. 17:834-844

Ramirez WA, Domene X, Ortiz O, Alcaniiz JM (2008b) Toxic effect of digested, composted and thermally-dried sewage sludge on Tyree plants. Bioresour Technol 99:7168-7175

Rodenburg LA, Ralston DK (2017) Historical sources of polychlorinated biphenyls to the sediment of the New York/New Jersey Harbor. Chemosphere 169(2017):450e459

Susarla S, Medina VF, McCutcheon SC (2002) Phytoremediation: an ecological solution to organic chemical contamination. Ecol Eng $18: 647-658$

Tarnawski M, Baran A, Koniarz T, Wyrębek M, Grela J, Piszczek M, Koroluk A (2017) The possibilities of the environmental use of bottom sediments from the silted inlet zone of the Rożnów reservoir. Geol Geophys Environ 43(4):335-344
Terzaghi E, Morselli M, Zanardini E, Morosini C, Raspa G, Di Guardo A (2018a) Improving the SoilPlusVeg model to evaluate rhizoremediation and PCB fate in contaminated soils. Environ Pollut 241:1138-1145

Terzaghi E, Zanardini E, Morosini C, Raspa G, Borin S, Mapelli F, Vergani L, Di Guardo A (2018b) Rhizoremediation half-lives of PCBs: role of congeners composition, organic carbon forms, bioavaibility, microbial activity, plant species and soil conditions, on the prediction of fate and persistence in soil. Sci Total Environ 612:544-560

Terzaghi E, Vergani L, Mapelli F, Borin S, Raspa G, Zanardini E, Morosini C, Anelli S, Nastasio P, Sale VM, Armiraglio S, Di Guardo A (2019) Rhizoremediation of weathered PCBs in a heavily contaminated agricultural soil: results of a biostimulation trial in semi field conditions. Sci Total Environ 686:484-496

Tu C, Ma L, Guo P, Song F, Teng Y, Zhang H, Luo Y (2017) Rhizoremediation of a dioxin-like PCB polluted soil by alfalfa: dynamic characterization at temporal and spatial scale. Chemosphere 189:517-524

U.S. Environmental Protection Agency (US EPA) (2002) Hudson River PCBs site New York. Record of Decision. http://www.epa.gov/ hudson/RecordofDecision-text.pdf

U.S. Environmental Protection Agency (US EPA) (2015) Statement from EPA on Hudson River cleanup. http://www3.epa.gov/hudson/pdf/ statement_hudson_october_1_final.pdf

Urbaniak M, Wyrwicka A, Zielinski M, Mankiewicz-Boczek J (2016) Potential for phytoremediation of PCDD/PCDF-contaminated sludge and sediments using Cucurbitaceae plants: a pilot study. Bull Environ Contam Toxicol 97(3):401-406

Urbaniak M, Zieliński M, Wyrwicka A (2017a) The influence of the Cucurbitaceae on mitigating the phytotoxicity and PCDD/PCDF content of soil amended with sewage sludge. Int J Phytorem 19(3): 207-213. https://doi.org/10.1080/15226514.2016.1207606

Urbaniak M, Wyrwicka A, Tołoczko W, Serwecińska L, Zieliński M (2017b) The effect of sewage sludge application on soil properties and willow (Salix sp.) cultivation. Sci Total Environ 586:66-75. https://doi.org/10.1016/j.scitotenv.2017.02.012

Vergani L, Mapelli F, Zanardini E, Terzaghi E, Di Guardo A, Morosini C, Raspa G, Borin S (2017) Phyto-rhizoremediation of polychlorinated biphenyls contaminated soils: an outlook on plant-microbe beneficial interactions. Sci Total Environ 575:1395-1406

White JC (2002) Differential bioavaibility of field-weathered p,p'-DDE to plants of the Cucurbita and Cucumis genera. Chemosphere 49:143152

Wyrwicka A, Steffani S, Urbaniak M (2014) The effect of PCBcontaminated sewage sludge and sediment on metabolism of cucumber plants (Cucumis sativus L.). Ecohydrol Hydrobiol 14:75-82

Wyrwicka A, Urbaniak M, Przybylski M (2019) The response of cucumber plants (Cucumis sativus L) to the application of PCBcontaminated sewage sludge and urban sediment. Peer J 7:e6743

Xu Y, Gregory KB, VanBriesen JM (2019) Reduction in sulfate inhibition of microbial dechlorination of polychlorinated biphenyls in Hudson and Grasse River sediments through fatty acid supplementation. Chemosphere 233(2019):81-91

Zhao X, Zheng M, Zhang B, Zhang Q, Liu W (2006) Evidence for the transfer of polychlorinated biphenyls, polychlorinated dibenzo-p-dioxins, and polychlorinated dibenzofurans from soil into biota. Sci Total Environ 368:744-752

Publisher's note Springer Nature remains neutral with regard to jurisdictional claims in published maps and institutional affiliations. 